\title{
PELAKSANAAN SERTIFIKASI HALAL LPPOM MUI TERHADAP PRODUK USAHA MIKRO, KECIL DAN MENENGAH (UMKM) (STUDI LPPOM MUI PROVINSI BENGKULU)
}

\author{
Ahmad Farhan \\ IAIN Bengkulu \\ farhan@gmail.com
}

\begin{abstract}
The issuance of Law Number 7 of 1996 concerning Products, Law Number 8 of 1999 Concerning Consumer Protection, Government Regulation Number 69 of 1999 reinforces the signal that the responsibility for halal food, beverage, medicines, cosmetics and other products is not only the responsibility of individuals and religious leaders alone, but also the responsibility of the government. Among the institutions responsible is the Food, Drug and Cosmetic Assessment Institute commonly called LPPOM. LPPOM MUI was established on January 6, 1989 to conduct halal examinations and certifications. According to Lukmanul Hakim as Director of LPPOM MUI Center that as a country that has the largest Muslim population, Indonesia has a big share in the world halal trade, reaching USD 197 billion of the total transaction estimated at US \$1,600 Billion. Seeing the huge potential of global Muslim consumption in Indonesia, LPPOM MUI as a halal certification institution in Indonesia must be able to present halal guaranteed products. Because Indonesia is also a big market for imported products such as food, medicine, cosmetics and other used goods.
\end{abstract}

Keywords: MUI, Halal Product, Islamic Law, Halal Certification

Abstrak. Dengan terbitnya Undang-undang Nomor 7 Tahun 1996 tentang Produk ${ }^{1}$,
Undang-undang Nomor 8 Tahun 1999 Tentang Perlidungan Konsumen ${ }^{1}$, Peraturan
Pemerintah Nomor 69 Tahun $1999^{1}$ menguatkan isyarat bahwa tanggung jawab
kehalalalan produk makanan, minuman, obat-obatan, kosmetik dan produk lainnya
tidak hanya menjadi tanggung jawab individu dan tokoh agama semata, tetapi juga
menjadi tanggung jawab pemerintah. Di antara lembaga yang bertanggung jawab adalah
Lembaga Pengkajian Pangan, Obat-obatan dan Kosmetik yang biasa disebut LPPOM.
LPPOM MUI didirikan pada tanggal 6 Januari 1989 untuk melakukan pemeriksaan dan
sertifikasi halal. Menurut Lukmanul Hakim selaku Direktur LPPOM MUI Pusat
bahwa sebagai Negara yang memiliki penduduk Muslim terbesar, maka Indonesia
punya andil besar dalam perdagangan halal dunia yakni mencapai USD 197 Miliar dari
total transaksi yang diperkirakan US\$ 1.600 Miliar. Melihat begitu besarnya potensi
konsumsi muslim global di Indonesia, LPPOM MUI sebagai lembaga sertifikasi halal di
Indonesia harus dapat menyajikan produk yang terjamin kehalalannya. Karena 
Indonesia juga menjadi pasar besar produk impor baik pangan, obat, kosmetik dan barang gunaan lainnya.

Kata Kunci: MUI, Produk Halal, Hukum Islam, Serifikat Halal

\section{Pendahuluan}

Dalam Pasal 5 Undang-Undang Nomor 23 Tahun 1992 tentang Kesehatan disebutkan bahwa setiap orang berkewajiban untuk ikut serta dalam memelihara dan meningkatkan derajat kesehatan perseorangan, keluarga, dan lingkungannya. ${ }^{1}$ Salah satu upaya untuk memelihara kesehatan perseorangan maupun keluarga adalah dengan memperhatikan apa yang dikonsumsi. Bahwa pangan $^{2}$ merupakan kebutuhan dasar manusia yang paling utama dan pemenuhannya menjadi hak asasi setiap rakyat Indonesia dalam mewujudkan sumber daya manusia yang berkualitas untuk melaksanakan pembangunan nasional. Disebutkan bahwa pangan yang aman, bermutu, bergizi, beragam, dan tersedia secara cukup merupakan prasyarat utama yang harus dipenuhi dalam upaya terselenggaranya suatu sistem pangan yang memberikan perlindungan bagi kepentingan kesehatan serta makin berperan dalam meningkatkan kemakmuran dan kesejahteraan rakyat.

Oleh karenanya, pangan sebagai komoditas dagang memerlukan dukungan sistem perdagangan pangan yang jujur dan bertanggung jawab sehingga tersedia pangan yang terjangkau oleh daya beli masyarakat serta turut berperan dalam peningkatan pertumbuhan ekonomi nasional. ${ }^{3}$ Sejalan dengan ini, Islam juga memberikan arahan agar setiap manusia hendaknya memperhatikan apa yang dia makan (Falyanzur al-Insan ila ta'amib: QS. 'Abasa/80: 24), ${ }^{4}$ baik dari segi cara

${ }^{1}$ Lihat http://hukum.unsrat.ac.id /uu/uu_23_92.htm, Diakses hari Senin, 1 Februari 2016, pukul 15.05 Wib. Lihat juga Modul Pelatihan Auditor Internal Halal, Dirjen Bimas Islam dan Penyelenggaraan Haji Departemen Agama RI, 2003, hal. 62.

2 Pangan adalah segala sesuatu yang berasal dari sumber hayati produk pertanian, pekerbunan, kehutanan, perikanan, peternakan, perairan dan air, baik yang diolah maupun tidak diolah diperuntukkan seagai makanan atau minuman bagi konsumsi manusia, termasuk baan tambahan pangan, bahan baku pangan, dan bahan lain yang digunakan dalam proses penyiapan, dan atau pembuatan makaan atau minuman. (Pasal 1 angka 1 Undang-Undang Nomor 18 Tahun 2012 tentan pangan).

${ }^{3}$ Lihat Undang-undang N0 18 Tahun 2012 tentang Pangan. www.hukumonline.com . Diakses hari Senin, 06 Januari 2016 pukul 16.00 Wib.

${ }^{4}$ Lihat Wahbah Zuhaili, dkk, al-Qur'an Seven in One, terj. Imam Ghazali Masykur. dkk, (PT. Almahira: Jakarta, 2009), hal. 45 
mendapatkannya maupun halal secara zat yang terkandung dalam makanan tersebut (Halal Tayyib). ${ }^{5}$

Dengan terbitnya Undang-undang Nomor 7 Tahun 1996 tentang Produk, ${ }^{6}$ Undang-undang Nomor 8 Tahun 1999 Tentang Perlidungan Konsumen ${ }^{7}$, Peraturan Pemerintah Nomor 69 Tahun $1999^{8}$ menguatkan isyarat bahwa tanggung jawab kehalalalan produk makanan, minuman, obat-obatan, kosmetik dan produk lainnya tidak hanya menjadi tanggung jawab individu dan tokoh agama semata, tetapi juga menjadi tanggung jawab pemerintah. Menjadi niscaya dan urgen bahwa makanan yang dikonsumsi oleh umat Islam selaku konsumen besar dari satu produk harus mendapatkan kepastian status kehalalannya. Secara syariat, mengkonsumsi produk halal bagi umat Islam merupakan kewajiban', dan demi kualitas hidup dan kehidupan, merupakan hak warga Negara yang dijamin oleh Undang-Undang Dasar 1945 Khususnya Undang-Undang Perlindungan Konsumen Nomor 8 Tahun 1999. ${ }^{10}$

Dengan demikian, Indonesia sebagai Negara dengan mayoritas muslim tepat kiranya memiliki Majelis Ulama Indonesia sebagai wadah atau majelis yang menghimpun para ulama, zuama dan cendekiawan muslim Indonesia untuk menyatukan gerak dan langkah-langkah umat Islam Indonesia dalam mewujudkan cita-cita bersama. ${ }^{11}$ Di antara lembaga yang dimaksud adalah Lembaga Pengkajian Pangan, Obat-obatan dan Kosmetik yang biasa disebut LPPOM. LPPOM MUI didirikan pada tanggal 6 Januari 1989 untuk melakukan pemeriksaan dan sertifikasi halal.

5 "Hai sekalian manusia, makanlah yang halal lagi baik dari apa yang terdapat di bumi, dan janganlah kamu mengikuti langkah-langkah syaitan; karena sesungguhnya syaitan itu adalah musuh yang nyata bagimu." QS. al-Baqarah/2: 168. Wahbah Zuhaili, dkk, al-Qur'an ..., hal. 435

${ }^{6}$ http://ews.kemendag.go.id. Diakses hari Senin, 1 Februari 2016, pukul 15.15 Wib.

${ }^{7}$ http://www.esdm.go.id/prokum/uu/1999/. Diakses hari Senin, 1 Februari 2016, pukul $15.18 \mathrm{Wib}$

${ }^{8}$ http://ditjenspk.kemendag.go.id / files / regulasi /1999/07/21/label-dan-iklan-pangan-id1376540604. Diakses hari Senin, 1 Februari 2016, pukul 15.18 Wib

9 Amirsya Tambunan, “Hak Konsumen Dalam Perspektif UU No. 8 Tahun 1999”, dalam Jurnal Halal, No. 101 Th. XVI Tahun 2013, (Jakarta: LPPOM MUI), hal. 16.

10 Anton Apriyantono, "LPPOM Harus diperkuat" dalam Jurnal Halal, No. 99 Th. XVI Tahun 2013, (Jakarta: LPPOM MUI), hal. 48.

${ }^{11}$ Majelis Ulama Indonesia berdiri pada tanggal, 7 Rajab $1395 \mathrm{H}$, bertepatan dengan tanggal 26 Juli 1975 di Jakarta, sebagai hasil dari pertemuan atau musyawarah para ulama, cendekiawan dan zu'ama yang datang dari berbagai penjuru tanah air. Momentum berdirinya MUI bertepatan ketika bangsa Indonesia tengah berada pada fase kebangkitan kembali, setelah 30 tahun merdeka, di mana energi bangsa telah banyak terserap dalam perjuangan politik kelompok dan kurang peduli terhadap masalah kesejahteraan rohani umat. Lihat http://mui.or.id/tentangmui/profil-mui, diakses hari Selasa, 9 Februari 2016, pukul 20..05 Wib 
Menurut Lukmanul Hakim selaku Direktur LPPOM MUI Pusat bahwa sebagai Negara yang memiliki penduduk Muslim terbesar, maka Indonesia punya andil besar dalam perdagangan halal dunia yakni mencapai USD 197 Miliar dari total transaksi yang diperkirakan US\$ 1.600 Miliar. ${ }^{12}$ Melihat begitu besarnya potensi konsumsi muslim global di Indonesia, LPPOM MUI sebagai lembaga sertifikasi halal di Indonesia harus dapat menyajikan produk yang terjamin kehalalannya. Karena Indonesia juga menjadi pasar besar produk impor baik pangan, obat, kosmetik dan barang gunaan lainnya.

Terkhusus dengan produk pangan, maka UMKM (Usaha Mikro Kecil dan Menengah) merupakan pelaku ekonomi nasional maupun lokal mempunyai peran yang sangat penting dalam pembangunan perekonomian. Akan tetapi, produk yang dihasilkanpun harus memperhatikan asas kehalalannya yang kemudian dibuktikan dengan sertifikasi halal yang dikeluarkan oleh MUI setempat termasuk di Provinsi Bengkulu. Banyaknya produk makanan dan minuman olahan, obat-obatan, dan kosmetika, tentu merupakan masalah tersendiri yang perlu dipertimbangkan masyarakat muslim, karena dorongan menjalani ajaran agama, menghendaki agar produk-produk yang dikonsumsi terjamin kehalalan dan kesuciannya secara hukum.

Berdasarkan observasi awal peneliti, produk UMKM di Kota Bengkulu sebagian telah mendapatkan sertifikasi halal sesuai dengan pengajuan dan permintaan dari pelaku usaha. Data ini didasarkan dari dokumen yang diambil dari LPPOM MUI Provinsi Bengkulu yakni terdapat 217 produk UMKM yang telah disertifikasi halal rentang tahun 2003-2016. ${ }^{13}$ Diantaranya produk makanan seperti masakan padang, masakan Sunda, Roti, Kue Bolu, Siomay. Begitu juga beberapa jenis minuman seperti air mineral kemasan, Kopi Kito, Sirup Kalamansi, air minum mineral dan lain sebagainya.

Selain itu, peneliti juga mendapatkan informasi bahwa ada rumah makan atau restoran Sea Food "Dermaga One" yang bertempat di Jalan Sudirman Pintu Batu yang telah mencantumkan logo Halal. Akan tetapi, berdasarkan keterangan LPPOM MUI sendiri bahwa Restoran tersebut belum pernah mengajukan sertifikasi halal dan atau mendapatkan sertifikat halal dari MUI. ${ }^{14}$ Dengan kata lain, ketika pencantuman lebel Halal MUI yang dilakukan sebuah UMKM sementara belum mendapatkan sertifikasi halal, ini menjadi preseden

12 “Advertorial” daiam Jurnal Halal, No. 115 Th. XVII Tahun 2015, (Jakarta: LPPOM MUI), hal. 16.

${ }^{13}$ Data dan Wawancara dengan Indra, Staff LPPOM MUI Provinsi, Selasa, 9 Februari 2016

14 Wawancara dengan Indra, Staff LPPOM MUI Provinsi Bengkulu, Senin, 8 Februari 2016, pukul. 12.05 wib. 
buruk bagi konsumen. Karena ada upaya penipuan publik dengan menyatakan kehalalan produk yang dijual padahal belum mendapatkan sertifikat halal. Dalam data lain, ada juga usaha Depot Air "Yusuf Mineral" yang beralamatkan di Jl. Kapuas Raya No. 14 D Lingkar Barat yang mencantumkan logo Halal Illegal. ${ }^{15}$ Maksudnya usaha tersebut mencantumkan logo Halal versi lama dan tidak resmi. Karena logo Halal yang diakui dan resmi diperoleh melalui proses sertifikasi halal dari MUI.

Terkait dengan beberapa kasus di atas, menurut peneliti ada beberapa asumsi yang bisa dikemukakan. Pertama, adanya anggapan penggiat usaha bahwa proses pelaksanaan sertifikasi Halal adalah suatu yang sulit dan ribet karena harus melengkapi berbagai persyaratan yang harus dipenuhi seperti menyerahkan spesifikasi teknis dari bahan baku dan tambahan bahan penolong yang digunakan dan foto copy HO. ${ }^{16}$ Kedua, adanya anggapan dari pelaku usaha bahwa proses pelaksanaan sertifikasi halal membutuhkan biaya yang besar, sehingga muncul rasa ketidakinginan melakukan proses sertifikasi. Ketiga, kurangnya kesadaran pelaku usaha akan pentingnya perlindungan konsumen dengan apa yang dikonsumsinya, terlebih bagi masyarakat muslim yang butuh jaminan halal.

Dari apa yang telah dipaparkan sebelumnya, maka peneliti malkukan penelitian terkait proses pelaksanaan sertifikasi Halal Lembaga Pengkajian Pangan Obat-obatan dan Kosmetik (LPPOM) MUI Provinsi Bengkulu terhadap produk Usaha Mikro, Kecil dan Menengah (UMKM).

\section{Hasil dan Pembahasan}

Dalam melakukan penelitian ini, penulis mengumpulkan data-data penelitian dengan cara observasi, wawancara dan dokumentasi. Untuk menguji keabsahan data yang telah diperoleh peneliti menggunakan teknik triangulasi. Adapun triangulasi yang dimaksud dalam penelitian ini adalah triangulasi dengan sumber dan metode, yang berarti membandingkan dan mengecek balik kebenaran informasi dan data yang diperoleh melalui waktu dan alat yang berbeda dalam metode kualitatif.

${ }^{15}$ Wawancara dengan Indra, Staff LPPOM MUI Provinsi Bengkulu, Senin, 8 Februari 2016, pukul. 12.15 wib.

${ }^{16}$ Syarat-syarat kelengkapan permohonan sertifikasi halal: 1). Mengisi Formulir Pendaftaran (disediakan LPPOM MUI). 2) Menyerahkan spesifikasi teknis dari bahan baku, bahan tambahan dan bahan penolong yang digunakan. 3). Diagram alur proses produksi produk. 4). Peta lokasi pabrik. 5). Tata letak/lay out Pabrik. 6). Copy P-IRT. 7). Copy MD. 8). Copy tanda tangan pemiliki atau Pimpinan Perusahaan. 9). Copy HO dari Pemerintah Setempat. Dokumen LPPOM MUI Provinsi Bengkulu. 
Adapun teknik analisa yang digunakan adalah interactive model yang mengklasifikasikan analisa data kepada tiga langkah yaitu: ${ }^{17}$ Pertama, Reduksi data (Data Reduction) Reduksi data adalah suatu proses pemilahan, pemusatan perhatian pada penyederhanaan, pengabstrakan dan transformasi data kasar yang muncul dari catatan-catatan tertulis di lapangan. Kedua Penyajian data (Data Display) Data yang diperoleh dari hasil observasi dan wawancara akan disusun sedemikian rupa, sehingga memberikan kemungkinan adanya penarikan kesimpulan. Ketiga, Penarikan kesimpulan (Verification). Dalam penelitian ini akan diungkap mengenai makna dari data yang dikumpulkan. Ketika ada keraguan, kekakuan dari kesimpulan yang ada, maka diperlukan verifikasi. Verifikasi ini dilakukan dengan meperhatikan kembali reduksi data maupun display data sehingga kesimpulan yang diambil tidak menyimpang atau sesuai dengan tujuan penelitian.

Tragedi nasional tentang merabaknya isu lemak babi pada bulan Desember 1988 yang mengguncang ketenangan batin umat Islam di Inonesia, menyebabkan para Ulama, pakar dan cendikiawan muslim bersepakat membentuk Lembaga Pengkajian Pangan Obat-obatan dan Kosmetika Majelis Ulama Indonesia yang disingkat LPPOM MUI. Lembaga ini dikukuhkan dengan SK No. KEP 018/MUI/I/1989 tanggal 06 Januari 1989 M/28 Jumadil Awal $1409 \mathrm{H}^{18}$ Sesuai dengan amanah MUI, lembaga ini berusaha menangani berbagai masalah pangan, obat dan kosmetika yang berhubungan dengan kehalalan produk tersebut.

Pada tahun 1991, dalam rangka pelaksanaan Tri Darma Perguruan Tinggi yakni pengabdian masyarakat, IPB memberikan izin kepada beberapa tenaga ahli untuk berkiprah untuk membantu Majelis Ulama Indonesia. Kerja sama tersebut tertuang dalam SK No. 023/PT39.H/1993 dan 705/MUI/XI/1993. ${ }^{19}$

Oleh karenanya, agar dapat menciptakan ketenangan masyarakat serta mendapatkan kepastian halal pada satu produk di seluruh lapisan yang berada pada setiap daerah-daerah, maka dibentuklah LPPOM MUI di masing masing Provinsi. Hal ini berdasarkan putusan Rapat Kerja Nasional (Rakornas) MUI bersama Ketua-ketua MUI Provinsi seluruh Indonesia pada tanggal 13Agustus 1994 di Jakarta tentang LPPOM MUI.

\footnotetext{
${ }^{17}$ Matthew Miles dan A, Michael Huberman, Analisis Data Kualitatif: Buku Sumber Tentang Metode-metode Baru, (Jakarta: UI Press, 1992), hal, 20.

${ }^{18}$ http://www.halalmui.org/, diakses pada hari Senin, 08 Agustus 2016, pukul. 08.25 wib

19 Profile Lembaga Pengkajian Pangan, Obat-obatan dan Kosmetika Majelis Ulama Indonesia (LPPOM-MUI), Provinsi Bengkulu
} 
Menindak lanjuti putusan tersebut, maka Majelis Ulama Indoneisa Provinsi Bengkulu melakukan rapat pleno pada tanggal 20 November 2000 setelah mendengarkan saran dan masukan dari seluruh anggota sehingga menghasilkan kesepakatan pembentukan Lembaga Pengkajian Pangan, Obat-obatan dan Kosmetika Majelis Ulama Indonesia yang disingkat dengan LPPOM MUI Provinsi Bengkulu. Akhirnya, pada tanggal 28 April 2001 LPPOM MUI Provinsi Bengkulu resmi terbentuk. ${ }^{20}$

Visi Misi LPPOM MUI Provinsi Bengkulu

Visi:

Menjadi lembaga sertifikasi halal terpercaya di Indonesia dan dunia untuk memberikan ketenteraman bagi umat Islam serta menjadi pusat halal dunia yang memberikan informasi, solusi dan standar halal yang diakui secara nasional dan internasional.

Misi:

1. Menetapkan dan mengembangkan standar halal dan standar audit halal.

2. Melakukan sertifikasi produk pangan, obat dan kosmetika yang beredar dan dikonsumsi masyarakat.

3. Melakukan edukasi halal dan menumbuhkan kesadaran masyarakat untuk senantiasa mengkonsumsi produk halal.

1. Menyediakan informasi tentang kehalalan produk dari berbagai aspek secara menyeluruh.

Struktur Organisasi LPPOM MUI Provinsi Bengkulu. Berdasarkan SK MUI dan SK Pengukuhan LPPOM MUI Pusat tanggal 08 Agustus 2011 sebagai berikut:

Ketua/Direktur : Ir. Edwar Suharnas, MP

Wakil Ketua : : Dr. Chairul Muslim, M. Sc

Sekretaris : Abdul Qohar, M. H.I

Auditor : : Drs. Supardi Mursalin, M. Ag

: Suwarjin MA

: Drs. M. Nesbah, MS

Staff Kantor $\quad$ : Indra. S.Kom. I

Pelaksanaan Sertifikasi Halal. Sosialisasi Makanan Halal dan Sertifikasi Halal.

Menurut Edwar Suharnas, bahwa LPPOM MUI Provinsi Bengkulu terus melakukan sosialisasi sertifikasi halal kepada pelaku Usaha Mikro Kecil dan Menengah. Hal ini dilakukan sebagai tanggung jawab lembaga untuk

20 Wawancara dengan Indra, Staf LPPOM MUI Provinsi Bengkulu, Rabu, 15 Juni 2016, pukul 11.45 wib. Lihat juga Profil LPPOM MUI Provinsi Bengkulu. 
mengingatkan dan memberikan pemahaman kepada produsen dan pelaku usaha, maupun masyarakat umum selaku konsumen tentang pentingnya mengkonsumsi makanan halal. Terlebih dengan adanya UU no 88 tahun 1999 tentang perlindungan konsumen terhadap apa yang dikonsumsinya. Berikut penuturannya:

"Pada dasarnya LPPOM MUI Provinsi Bengkulu terus melakukan sosialisasi tentang sertifikasi halal dan pentingnya makanan halal. Hal ini menjadi tanggung jawab moral dan kelembagaan untuk kami memberikan pemahaman kepada produsen (pelaku usaha) baik perusahaan besar maupun UMKM serta kepada masyarakat muslim khususnya selaku konsumen. Dalam pelaksanannya, LPPOM MUI diundang oleh dinas tertentu seperti Dinas Kesehatan, Dinas Koperasi dan UMKM untuk melakukan sosialisasi makanan halal dan sistem sertifikasi halal."21

Selain itu, berdasarkan petunjuk dari LPPOM MUI Pusat, guna melakukan sosialisasi dimaksud, maka dilakukan beberapa kegiatan diantaranya: ${ }^{22}$

a). INDHEX (Indonesia International Halal Expo)

Dalam rangka edukasi dan promosi produk bersertifikat halal, LPPOM MUI menggelar event tahunan yaitu INDHEX, berupa Expo produk bersertifikat Halal dan berbagai event yaitu Global Halal Forum, Halal Award, aneka talkshow, halal competition, dan Halal Community Gathering. INDHEX 2014 akan dilaksanakan pada tanggal 23 s.d. 25 Oktober di Jakarta International Expo.

b) Olimpiade Halal

Dalam rangka memperingati Milad LPPOM MUI yang ke-25, LPPOM MUI menyelenggarakan Olimpiade Halal 2014 LPPOM MUI antar SMU tingkat Nasional. Kegiatan ini akan dilaksanakan setiap tahun untuk menumbuhkan dan meningkatkan kepedulian generasi muda terhadap produk halal dan menerapkan gaya hidup halal "Halal is My Life" dalam kehidupan sehari-hari. Ujian dilaksanakan melalui program HaLO (Halal Learning Online) LPPOM MUI. Pada tahun 2014 ini olimpiade diikuti oleh 2.964 peserta dari seluruh provinsi di Indonesia.

Sejalan dengan itu, Indra menyatakan bahwa adakalanya pengurus LPPOM MUI Provinsi Bengkulu mendapatkan laporan dari masyarakat tentang satu usaha yang diragukan kehalalannya terlebih tidak memiliki sertifikasi halal apalagi label halal dari MUI. Untuk merespon laporan tersebut, LPPOM MUI Provinsi Bengkulu mengirimkan surat kepada produsen atau pelaku usaha agar

\footnotetext{
${ }^{21}$ Wawancara dengan Subyek Penelitian, Sabtu, 27 Juni 2016, pukul .10 .00 wib

22 LIhat http://www.halalmui.org, diakses Jum'at, 25 Agustus 2016, pukul 22.15 wib
} 
mengurus sertifikasi halal untuk kemudian diaudit oleh LPPOM MUI. Dia menyebutkan:

"Dalam pelaksanaan sertifikasi halal, LPPOM MUI terkadang mendapat laporan dari masyarakat terkait makanan atau satu usaha yang belum bersertifikat halal MUI. Adakalanya, kami juga selaku konsumen pada sebuah rumah makan bertanya tentang ada atau tidak sertifikat halal pada produknya. Jika belum, diminta untuk. mengajukan permohonan sertifikasi halal ke LPPOM MUI Provinsi Bengkulu. ${ }^{, 23}$

a. Prosedur Sertifikasi Halal

Menurut Edward Suharnas, LPPOM MUI Provinsi Bengkulu telah membuat prosedur sebagaimana berikut: ${ }^{24}$

a) Produsen mengajukan surat permohonan sertifikasi halal.

b) Produsen melengkapi persyaratan permohonan.

c) Produsen membuat daftar spesifikasi halal bahan baku, bahan tambahan dan bahan penolong serta bagian alur proses produksi.

d) Produsen Menandata tangani surat kontrak dan melakukan pembayaran.

e) LPPOM MUI melakukan pemeriksaan terhadap kelengkapan berkas

f) LPPOM MUI melakukan audit di lokasi.

g) LPPOM MUI melakukan evaluasi bersama tim ahli.

h) Komisi Fatwa MUI melakukan telaah dalam perspektif hukum syariat.

i) MUI Provinsi secara kelembagaan mengeluarkan Sertifikat Halal.

j) Perusahaan/UMKM yang produknya telah mendapat sertifikat halal harus mengangkat auditor halal internal sebagai bagian dari sistem jaminan halal.

Jika kemudian ada perubahan dalam penggunaan bahan baku, bahan tambahan, atau bahan penolong pada proses produksinya maka pihak auditor halal internal diwajibkan segera melapor untuk mendapatkan "ketitikberatan penggunaannya." 25

b. Borang dan daftar Isian Audit Produk Halal.

Berdasarkan informasi dari Indra, bahwa setiap produsen yang telah mengajukan permohonan sertifikasi halal, wajib mengisi borang atau pedoman isian audit produk halal. Pedoman ini pada prinsipnya untuk memudahkan produsen menyiapkan sistem halal dan memudahkan tim LPPOM MUI dalam melakukan audit di lokasi produsen. Pedoman ini hanya mencakup hal-hal

23 Wawaancara dengan Indra, Staff Kantor LPPOM MUI,

24 Wawancara dengan Edward Suharnas, Direktur LPPOM MUI Provinsi Bengkulu, Sabtu, 23 Juli 2016. Secara umum, bisa juga dilihat di http:/ /www.halalmui.org.

${ }^{25}$ Lihat juga http://www.seputarukm.com. Diakses Sabtu, 13 Agustus 2016, pukul 11.25 wib. 
yang berhubungan secara langsung dengan cara berproduksi yang halal, dan tidak mencakup secara rinci tentang bagaimana cara berproduksi yang baik. ${ }^{26}$

Pedoman ini disusun dengan tujuan agar pemeriksan mempunyai keseragaman pandangan dan metode di dalam melakukan audit di lokasi produsen. Oleh karena sifanya yang umum, maka adanya kemungkinan penambahan sesuatu item yang dianggap perlu oleh pemeriksaan selama proses pemeriksaan.

Pedoman ini mencakup hal-hal yang perlu diperiksa selama kegiatan berlangsung. Pertama, Manajemen produsen dalam menjamin kehalalan produk meliputi system halal termasuk pedoman halal dan prosedur pelaksanaan baku (Standar operating procedure), dokumentasi upaya produsen dalam menjamin kehalalan produknya dan personalia penanggung jawab kehalalan produk. Kedua, observasi lapangan terkait dengan fasilitas, penyimpanan, pengangkutan, distribusi dan penjualan. Selanjutnya bagaimana cara berproduksi termasuk penggunaan bahan baku, bahann tambahan dan bahan penolong, cara pengolahan dan cara penggudangan dan penyimpanan.

Ketiga, dimungkinkan adanya pengambilan contoh pada titik kritis yaitu yang hanya diindikasikan mengandung babi atau turunannya, yang mengandung alkohol dan yang dianggap perlu lainnya.

c. Masa berlakunya sertifikat halal.

Bahwa sertifikat halal yang dikeluarkan MUI atas audit LPPOM MUI dan sidang Komisi Fatwa diatur sebagai berikut: ${ }^{27}$

a) Sertifikat halal hanya berlaku selama dua tahun. Untuk daging ekspor, surat keterangan halal diberikan untuk setiap pengapalan.

b) Tiga bulan sebelum berakhir masa berlakunya sertifikat, LP POM Majelis Ulama Indonesia akan mengirim surat pemberitahuan kepada produsen yang bersangkutan.

c) Dua bulan sebelum berakhir masa berlakunya sertifikat, produsen harus mendaftarkan produknya kembali utuk sertifikat halal yang baru.

d) Produsen yang tidak memperbaharui sertifikat halalnya, tidak diizinkan lagi menggunakan sertifikat halal tersebut. Kemehalal itu dihapus dari daftar yang terdapat dalam majalah resmi LPPOM Majelis Ulama Indonesia.

e) Jika sertifikat halal hilang, pemegang harus melaporkannya ke LPPOM Majelis Ulama Indonesia.

26 Lihat Pedoman Umum Pemeriksaan (Audit) Produk Halal LLPOM MUI Provinsi Bengkulu

27 http://www.halalmui.org. Lihat juga http://dinkop-umkm.jatengprov.go.id. Diakses Sabtu, 2 Juli 2016, pukul 16.25 Wib. 
f) Sertifikat halal yang dikeluarkan oleh Majelis Ulama Indonesia adalah milik MUI. Oleh karena itu, jika sesuatu hal diminta kemabali oleh MUI maka pemegang sertifikat halal wajib menyerahkannya.

g) Keputusan Mejelis Ulama Indonesia yang didasarkan atas fatwa MUI tidak dapat diganggu gugat.

Adapun terkait dengan prosedur perpanjangan sertifikat halal diatur juga dengan ketentuan sebagai berikut: ${ }^{28}$

a) Jika produsen bermaksud memperpanjang sertifikat yang dipegangnya, harus mengisi formulir pendaftaran yang telah disediakan.

b) Pengisian formulir disesuaikan dengan perkembangan terakhir produk.

c) Perubahan bahan baku, bahan tambahan, dan bahan penolong serta pengelompokkan produk harus diinformasikan kepada LP POM MUI.

d) Produsen berkewajiban melengkapi dokumen terbaru tentang spesifikasi, sertifikat halal, dan bagan alur proses.

a. Sosialisasi Makanan Halal dan Sertifikasi Halal.

Menurut informan penelitian, bahwa sosialisasi produk halal dan sertifikasi halal dilakukan dengan bekerja sama dengan pihak instansi pemerintahan dan dinas seperti Dinas Kesehatan, Dinas Koperasi dan UMKM serta Dinas Perdagangan. Dalam kegiatan sosialisasi tersebut mengundang pelaku usaha dan masyarakat umum sesuai dengan kebutuhan penyelenggara kegiatan dan tujuan kegatan tersebut.

b. Prosedur Sertifikasi Halal.

Bahwa prosedur yang telah disusun oleh LPPOM MUI pada dasarnya cukup jelas dan tidak memberatkan produsen atau pelaku UMKM. Apalagi prosedur ini juga turunan dari prosedur yang telah ditetapkan oleh LPPOM MUI Pusat, sehingga LPPOM MUI Provinsi Bengkulu melaksanakannya dengan menyesuaikan kondisi UMKM. Salah satu yang masih ditemukan adalah ketiadaan SJH pada saat proses audit lapangan. Padahal SJH harus dipersiapkan sebelum pengajuan sertifikasi halal. Tetapi tidak menjadi penghalang proses audit. Setelah selesai auditing, tim LPPOM MUI Provinsi Bengkulu kembali menegaskan agar produsen menyiapkan SJH sebagai bentuk komitmen dan tanggung jawab terhadap produk halal.

Terkait dengan dana pembayaran sertifikasi halal, LPPOM MUI Provinsi Bengkulu membuat kebijakan sendiri dengan memperhatikan kondisi produsen usaha tersebut. Menurut Edward, bahwa UMKM dalam prakteknya dibagi kepada tiga kategori, yaitu kategori kecil, kategori sedang dan kategori besar. Sehingga dana yang perlu dipersiapkan untuk pengajuan dan pengurusan

${ }^{28}$ Hasil wawancara dengan Edwar Suharnas, di kantor LPPOM MUI Provinsi Bengkulu, 28 Juli 2016. Lihat juga http://www.halalmui.org. 
sertifikasi halal relatif murah yaitu Rp. 1.000 .000 untuk kategori kecil , Rp. 1.500.000 untuk kategori menegah sedang dan Rp. 2.000.000 untuk kategori besar. Selama ini, biaya yang ditentukan memang direspon sebagian produsen sesuatu yang mahal meskipun sebagian lainnya tidak masalah. Terlebih LPPOM MUI Pusat lebih tegas dalam memberlakukan biaya yang sudah menjadi ketentuan. Bahwa setiap UMKM dikenakan biaya sebesar Rp. 2.500 .000 dalam pengurusan sertifikasi halal. ${ }^{29}$

a. Borang dan Daftar Isian Audit Produk Halal.

Setiap Usaha yang mengajukan surat untuk mendapatkan sertifikasi halal, harus mengisi borang atau daftar isian audit produk halal. Daftar isian yang dimaksud meliputi meliputi manajemen produsen terkait kebijakan pembelian, kebijakan produksi dan kebijakan administrasi. Borang ini harus diisi sesuai apa yang dipertanyakan dan berbasis kejujuran produsen. Karena setiap jawaban akan dilakukan kroscek lapangan.

Sedangkan terkait kebijakan produksi, ada beberapa yang mesti dijawab oleh produsen terkait apakah yang diproduksi barang-barang yang halal, adakah konsistensi penggunaan bahan baku, bahan tambahan dan bahan penolong dalam produksinya. Selain itu konsistensi penggunaan bahan tersebut apakah mencakup jenis, nama produk dan pemasoknya. Ketika konsistensi itu memang ada, adakah dituangkan dalam bentuk tertulis. Jika ada perubahan bahan baku, apakah diketahui oleh penanggung jawab halal intenal usaha tersebut (auditor internal halal).

29 Diolah dari hasil wawancara dengan Edward, 27 Juni 2016.

A Partanto, Pius , Kamus Ilmiah Populer, Surabaya: Arkola: 1994.

Apriyantono, Anton "LPPOM Harus diperkuat" dalam Jurnal Halal, No. 99 Th. XVI Tahun 2013, Jakarta: LPPOM MUI.

“Advertorial” daiam Jurnal Halal, No. 115 Th. XVII Tahun 2015, Jakarta: LPPOM MUI

Bakker, Anton, Kamus Filsafat, Yogyakarta: Kanisius, 1992.

CD Ensiklopedia Hadis Sembilan, Jakarta: Lidwa Pusaka, tt.

CD Maktabah Syamilah, al-Isdar al-Sani, tt.

Fauzan, Nur Muhammad, "Peranan MUI Dalam Melindungi Konsumen Muslim dari Produk Haram (Studi Kebijakan LPPOM MUI D.I Yogkarta). Skripsi Fakultas Syariah dan Hukum, Universitas Islam Negeri (UIN) Sunan Kalijaga, 2015.

Haq, Abdul, Ahmad Mubarok, Agus Ro'uf, Formulasi Nalar Fiqib: Tela'ah Kaidah Fiqih Kontekstual, Surabaya: Khalista, 2005.

Kartono, Kartini, Pengantar Metodologi Riset Sosial, Bandung: Mandar Maju, 1996.

Moleong, Lexy J, Metodologi Penelitian Kualitatif, Bandung: Remaja Rosyada Karya, 2005.

Modul Pelatihan Auditor Internal Halal, Dirjen Bimas Islam dan Penyelenggaraan Haji Departemen Agama RI, 2003 
a. Audit di Lapangan.

Proses audit lapangan ini merupakan salah satu hal terpenting dalam pelaksanaan sertifikasi halal LPPOM MUI Provinsi. Audit ini dilaksanakan setelah ada kesepakatan waktu antara LPPOM MUI dan pelaku usaha. Peneliti turut serta bersama Tim LPPOM melakukan audit pada usaha Elly Bakery dan Pecel Lele Mang Udin. Pada proses ini, auditor mengklarifikasi terkait kebijakan produksi. Tim akan mempertanyakan segala sesuatu yang diiproduksi apakah berasal dari barang-barang yang halal, adakah konsistensi penggunaan bahan baku, bahan tambahan dan bahan penolong dalam produksinya.

Klarifikasi yang dilakukan pun dilanjutkan dengan melihat bagian produksi atau dapur untuk melakukan kroscek satu persatu bahan yang digunakan. Setiap bahan dipastikan apakah telah memiliki label halal atau tidak. Pengecekanpun juga dilakukan dengan aplikasi Androdi yaitu 'Cek Halal MUI. Dalam pengamatan peneliti, tim LPPOM MUI Provinsi Bengkulu masih mendapati bahwa produsen belum menampilkan Sistem Jaminan Halal. Selain itu, ada titik kritis makanan yang diragukan kehalalannya yang juga ditemukan seperti pada usaha Pecel Lele Mang Udin, yakni belum adanya kepastian apakah daging yangdipotong secara islam atau minimal ada surat keterangan dari rumah potong hewan.

Asumsi penulis, boleh jadi ini menjadi problem bahwa banyak usaha potong hewan seperti bebek, ayam yang belum penya sertifikasi halal bagi pemotong dan proses pemotongannya. Sehingga ini menjadi penting bagi LPPOM MUI untuk terus mensosialisasikan tentang produksi halal dan sertifikat halal demi menjamin kepastian halal produk kepada konsumen.

b. Masa berlaku sertifikat halal.

Menurut peneliti, bahwa masa berlakunya sertifikat halal relatif singkat yakni selama dua tahun. Terlebih setiap enam bulan sekali LPPOM MUI akan melakukan pengecekan secara berkala. Berdasarkan hasil wawancara dan observasi bahwa ketiak tiga bulan sebelum berakhir masa berlakunya sertifikat, LPPOM Majelis Ulama Indonesia akan mengirim surat pemberitahuan kepada produsen yang bersangkutan. Selanjjutnya, pada saat dua bulan sebelum berakhir masa berlakunya sertifikat, produsen harus mendaftarkan produknya kembali utuk sertifikat halal yang baru. Produsen yang tidak memperbaharui 
sertifikat halalnya, tidak diizinkan lagi menggunakan sertifikat halal tersebut. Meski demikian, apa yang peneliti temukan ternyata banyak Usaha yang tidak melakukan perpanjangan sertifakat halal sedangkah masa berlakunya sudah lama habis. Inilah efek dari kebijakan Negara tentang sertifikasi halal yang bersifat voluntary bukan mandatory.

c. Daftar UMKM yang telah disertifikasi halal LPPOM MUI.

Umumnya UMKM yang telah terdaftar di pada produk halal LPPOM MUI Provinsi Bengkulu merupakan produk makanan dan minuman diantaranya seperti Bakso, Roti dan Kue Bolu, Rumah Makan, air minum dalam kemasan. Minuman kopi dan teh. Dari daftar disebutkan ada 197 UMKM di Provinsi Bengkulu yang telah disertifikasi, dengan rincian 92 UMKM yang telah habis masa berlakunya dan 105 yang masih berlakunya. Untuk UMKM yang tidak melakukan perpanjangan umumnya karena masalah keuangan dan memang menganggap tidak perlu lagi untuk melakukan lagi dengan dalih telah melakukan sertifikasi sebelumnya.

\section{Penutup}

Dari analisa penelitian yang telah dilakukan peneliti, maka pelaksanaan sertifikasi halal LPPOM MUI Provinsi Bengkulu terhadap produk UMKM dapat diambil kesimpulannya sebagai berikut:

Pertama, bahwa LPPOM MUI melakukan sosialisasi sertifikasi halal dan produk halal kepada instansi, dinas atau masyarakat umum baik diminta ataupun berdasarkan tugas lembaga dan program kerjanya sendiri. Di antara Dinas yang telah meminta LPPOM MUI untuk melakukan sosialisasi adalah Dinas Kesehatan Provinsi Bengkulu, Dinas Koperasi dan UMKM, Dinas Perdagangan.

Kedua, bahwa LPPOM MUI memiliki prosedur yang telah ditetapkan untuk pelaksanaan sertifikasi halal yang harus diikuti oleh produsen atau pelaku UMKM.

Ketiga, pengisian borang atau daftar isian audit produk halal adalah tahapan prosedur penting yang harus diperhatikan dan diisi oleh produsen guna mendapatkan sertifikasi halal.

Keempat, adanya proses audit di lapangan lokasi oleh tim LPPOM MUI Provinsi Bengkulu guna mendapatkan kepastian dari info dan data yang telah diisi dalam Daftar Isian Audit produk halal.

Kelima, masa berlakunya sertifikat halal MUI adalah selama 2 tahun dan diberikan hak untuk memperpanjangnya dengan syarat dan ketentuan yang berlaku. 
Kelima, terdapat 197 UMKM di Provinsi Bengkulu yang telah disertifikasi, dengan rincian 92 UMKM yang telah habis masa berlakunya dan 105 yang masih berlakunya. Untuk UMKM yang tidak melakukan perpanjangan umumnya karena masalah keuangan dan memang menganggap tidak perlu lagi untuk melakukan lagi dengan dalih telah melakukan sertifikasi sebelumnya. Sedangkan dari LPPOM MUI tetap mengirimkan surat pemberitahuan dan himbauan kepada UMKM.

\section{Daftar Pustaka}

Undang-undang No 18 Tahun 2012 tentang Pangan. www.hukumonline.com . Diakses hari Senin, 06 Januari 2016 pukul 16.00 Wib.

Wahbah Zuhaili, dkk, al-Qur'an Seven in One, terj. Imam Ghazali Masykur. dkk, (PT. Almahira: Jakarta, 2009), hal. 45

http://ews.kemendag.go.id. Diakses hari Senin, 1 Februari 2016, pukul 15.15 Wib.

http://www.esdm.go.id /prokum/uu /1999/. Diakses hari Senin, 1 Februari 2016, pukul 15.18 Wib

http://ditjenspk.kemendag.go.id / files / regulasi /1999/07/21/label-daniklan-pangan-id-1376540604. Diakses hari Senin, 1 Februari 2016, pukul 15.18 Wib

Amirsya Tambunan, "Hak Konsumen Dalam Perspektif UU No. 8 Tahun 1999”, dalam Jurnal Halal, No. 101 Th. XVI Tahun 2013, Jakarta: LPPOM MUI), hal. 16.

Anton Apriyantono, "LPPOM Harus diperkuat" dalam Jurnal Halal, No. 99 Th. XVI Tahun 2013, (Jakarta: LPPOM MUI), hal. 48. 16.

Jurnal Halal, No. 115 Th. XVII Tahun 2015, (Jakarta: LPPOM MUI), hal.

Matthew Miles dan A, Michael Huberman, Analisis Data Kualitatif: Buku Sumber Tentang Metode-metode Baru, (Jakarta: UI Press, 1992), hal, 20.

http://www.halalmui.org/, diakses pada hari Senin, 08 Agustus 2016, pukul. 08.25 wib

http://www.halalmui.org, diakses Jum'at, 25 Agustus 2016, pukul 22.15 wib

http://www.seputarukm.com. Diakses Sabtu, 13 Agustus 2016, pukul 11.25 wib.

http:/ /www.halalmui.org. Lihat juga http://dinkop-umkm.jatengprov.go.id. Diakses Sabtu, 2 Juli 2016, pukul 16.25 Wib.

A Partanto, Pius , Kamus Ilmiah Populer, Surabaya: Arkola: 1994.

Apriyantono, Anton “LPPOM Harus diperkuat” dalam Jurnal Halal, No. 99 Th. XVI Tahun 2013, Jakarta: LPPOM MUI.

Jurnal Halal, No. 115 Th. XVII Tahun 2015, Jakarta: LPPOM MUI

Bakker, Anton, Kamus Filsafat, Yogyakarta: Kanisius, 1992. 
Fauzan, Nur Muhammad, "Peranan MUI Dalam Melindungi Konsumen Muslim dari Produk Haram (Studi Kebijakan LPPOM MUI D.I Yogkarta). Skripsi Fakultas Syariah dan Hukum, Universitas Islam Negeri (UIN) Sunan Kalijaga, 2015.

Haq, Abdul, Ahmad Mubarok, Agus Ro'uf, Formulasi Nalar Fiqib: Tela'ah Kaidah Fiqih Kontekstual, Surabaya: Khalista, 2005.

Kartono, Kartini, Pengantar Metodologi Riset Sosial, Bandung: Mandar Maju, 1996.

Moleong, Lexy J, Metodologi Penelitian Kualitatif, Bandung: Remaja Rosyada Karya, 2005.

Modul Pelatihan Auditor Internal Halal, Dirjen Bimas Islam dan Penyelenggaraan Haji Departemen Agama RI, 2003 